\title{
Pyogenic liver abscess complicated by a hepatoduodenal fistula
}

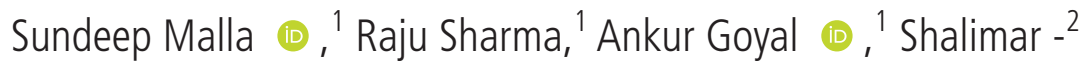

${ }^{1}$ Radiodiagnosis, All India Institute of Medical Sciences, New Delhi, Delhi, India ${ }^{2}$ Gastroenterology and Human Nutrition, All India Institute of Medical Sciences, New Delhi, Delhi, India

\section{Correspondence to}

Dr Ankur Goyal;

ankurgoyalaiims@gmail.com

Accepted 18 May 2021
Check for updates

(C) BMJ Publishing Group Limited 2021. No commercial re-use. See rights and permissions. Published by BMJ.

To cite: Malla S, Sharma R, Goyal A, et al. BMJ Case Rep 2021;14:e242693. doi:10.1136/bcr-2021242693

\section{DESCRIPTION}

A 45 -year-old man presented with right upper abdominal pain and low-grade fever for 2 weeks. Laboratory investigations showed polymorphonuclear leukocytosis with normal liver function tests. Ultrasound scan showed a heteroechoic lesion in the right lobe of the liver with mobile echogenic foci causing dirty acoustic shadowing, suspicious of air-containing lesion. A contrast-enhanced CT scan of the abdomen was done, which showed a well-defined 5.5 $\mathrm{cm} \times 6 \mathrm{~cm}$ hypodense peripherally enhancing lesion in the right lobe of liver with multiple air foci within, suggestive of an abscess. There was a communication of the inferomedial wall of abscess with the first part of duodenum, indicative of fistulisation (figure 1). A CT-guided pigtail catheter drainage of the abscess as well as of the subcapsular collection was done. A tubogram through the pigtail catheter placed in the liver abscess showed opacification of the first part of duodenum (figure 2) confirming the diagnosis of a hepatoduodenal fistula complicating a liver abscess. Aspiration revealed frank pus, which grew Escherichia coli on culture. In addition to the catheter drainage, the patient was started on intravenous ciprofloxacin and metronidazole initially followed by meropenem for a total duration of 21 days and the symptoms resolved completely. Enterohepatic fistula is a very rare complication of liver abscess seen in $1.5 \%$ cases. ${ }^{1}$ Detection of air in a liver abscess cavity should raise the possibility of either a hepatobronchial fistula, hepatoenteric

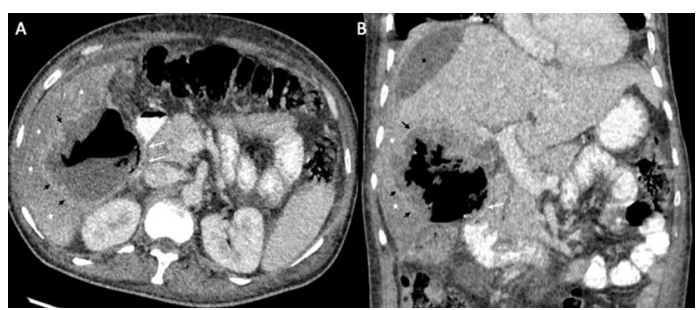

Figure 1 Contrast-enhanced $\mathrm{CT}(\mathrm{A}, \mathrm{B})$ axial and coronal images with positive oral contrast showing an air-containing abscess in the right lobe of liver with the inferomedial wall of the abscess fistulising into the duodenum (white arrows). Short black arrows depict the wall of the abscess and white asterisks denote the hypodense edematous surrounding liver parenchyma. Black asterisk denotes the subcapsular collection, which was seen communicating with the liver abscess.

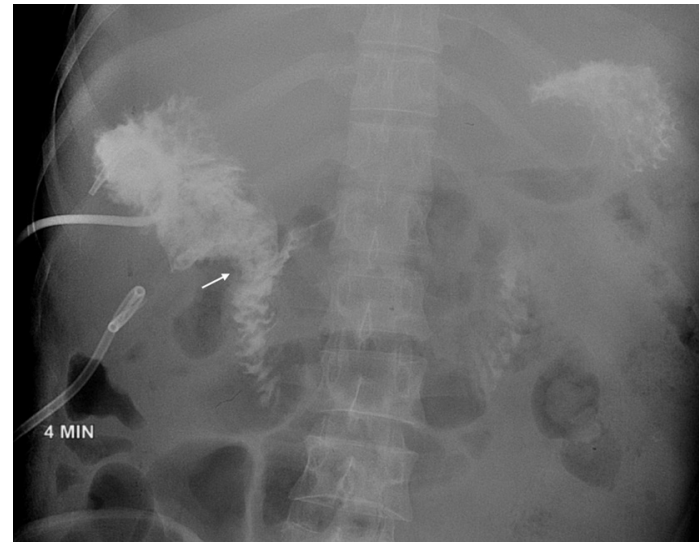

Figure 2 Instillation of non-ionic iodinated contrast through the drainage catheter inserted in the abscess cavity shows opacification of the duodenum suggestive of a hepatoduodenal fistula.

fistula or secondary bacterial infection by an air-producing organism. ${ }^{2}$ The common sites of fistulisation include stomach, colon and duodenum. ${ }^{23}$ Contrast-enhanced CT scan with positive oral contrast or instillation of contrast through the drainage catheter placed in the abscess cavity are the definitive investigations for demonstration of the fistula. There are no standard treatment guidelines for managing this complication. Although surgical management may be definitive, conservative management with catheter drainage may also help in the spontaneous closure of the fistula. ${ }^{4}$ It is important to remember that in addition to liver abscess, the other lesions responsible for hepatoenteric fistula may include malignant neoplasms (of gall bladder/liver/colon) as well.

\section{Learning points}

- Detection of air in a liver abscess cavity should raise the possibility of either a hepatobronchial fistula, hepatoenteric fistula or secondary bacterial infection by an air-producing organism.

- Enterohepatic fistula is a very rare complication of liver abscess.

- Common sites of fistulisation include stomach, colon and duodenum.

Contributors SM: original draft, conception and design. RS: drafting the article,critical revision and final approval. AG: 
Images in...

conception and design, drafting, critical revision and final approval of the article. Sh: critical revision and final approval.

Funding The authors have not declared a specific grant for this research from any funding agency in the public, commercial or not-for-profit sectors.

Competing interests None declared.

Patient consent for publication Obatined.

Provenance and peer review Not commissioned; externally peer reviewed.

\section{ORCID iDs}

Sundeep Malla http://orcid.org/0000-0002-8504-5659

Ankur Goyal http://orcid.org/0000-0003-3333-370

\section{REFERENCES}

1 Yang DM, Kim HN, Kang JH, et al. Complications of pyogenic hepatic abscess: computed tomography and clinical features. I Comput Assist Tomogr 2004;28:311-7.

2 Lamba AS, Singh B, Gupta M, et al. Hepato-Duodenal fistula complicating a pyogenic liver abscess: an unusual presentation. Cureus 2020;12:e12236.

3 Timbol ABG, Mondragon KAM, Banez VP. Hepatocolic fistula: a rare presentation of pyogenic liver abscess. BMJ Case Rep 2017;2017. doi:10.1136/bcr-2016-219141. [Epub ahead of print: 08 Mar 2017].

4 Ishwar M, Tambat R, Srinivas NM. Nature heals: spontaneous resolution of liver abscess through hepato-colic fistula. IJSS Case Rep Rev 2015;1:27-9.

Copyright 2021 BMJ Publishing Group. All rights reserved. For permission to reuse any of this content visit

https://www.bmj.com/company/products-services/rights-and-licensing/permissions/

BMJ Case Report Fellows may re-use this article for personal use and teaching without any further permission.

Become a Fellow of BMJ Case Reports today and you can:

- Submit as many cases as you like

- Enjoy fast sympathetic peer review and rapid publication of accepted articles

- Access all the published articles

- Re-use any of the published material for personal use and teaching without further permission

Customer Service

If you have any further queries about your subscription, please contact our customer services team on +44 (0) 2071111105 or via email at support@bmj.com.

Visit casereports.bmj.com for more articles like this and to become a Fellow 